\title{
Quality of Life Assessment in Elderly Served at Family Health Strategy Unit
}

\begin{abstract}
Ana Margareth Marques Fonseca Sarmento', Maria de Lourdes de Farias Pontes², Valeria Peixoto Rodrigues ${ }^{2}$, Cleane Rosa da Silva ${ }^{3}$, Sergio Augusto Silva Paredes Moreira4, Jordana de Almeida Nogueira ${ }^{2}$, Luiz Fernando Rangel Tura ${ }^{5}$, Antonia Oliveira Silva2, Olívia Galvão Lucena Ferreira ${ }^{6}$, Maria Adelaide Silva Paredes Moreira ${ }^{7}$
\end{abstract}

\section{Abstract}

Introduction: The increasing number of the elderly population occurred in Brazil took radical and accelerated way, considered an unprecedented event that has been following a worldwide phenomenon, which affects the society and reflects on the actions turned to the specific needs of the elderly. Concern related to the quality of life of the elderly is inherent in living conditions that the same will face as a commitment to their health conditions occur.

Objective: Evaluating the quality of life of elderly in teams of the Family Health Strategy in the municipality of João Pessoa/PB.

Methods: Study of secondary database of a quantitative approach carried out in the municipality of João Pessoa (JP) - Paraíba/Brazil, at the Units of the Family Health Strategy with 250 elderly, used as a survey instrument a questionnary, the WHOQOL-BREF and WHOQOLOLD. Data were analyzed using SPSS 13.0. The average measurements were calculated, median, standard deviation and absolute frequency, as well as the domains and facets of the Quality of Life.

Results: There was a prevalence of female elderly (70.4\%); older "young", aged between 60-79 years old (85.2\%), married (44.8\%), of low education level, between 1-4 years of education (30.4\%), and family income from 1-3 minimum wages (70.8\%). In the overall assessment of the quality of life it was possible to evaluate the perception of the elderly on the quality of life and satisfaction with health, where $52.0 \%$ of seniors considered their quality of life good and $50.4 \%$ were satisfied with their health.
1 Physiotherapist, master's degree in Nursing from the Federal University of Paraíba. João Pessoa, Paraíba, Brazil.

2 Nurse. Doctor. Professor of the Graduate Program in Nursing, Federal University of Paraíba. João Pessoa, Paraíba, Brazil.

3 Nurse. Graduate student. Student of the Post-Graduate Nursing - Federal University of Paraíba. João Pessoa, Paraíba, Brazil.

4 Doctor. Master's degree. Student of the Post-Graduate Nursing - Federal University of Paraíba. João Pessoa, Paraíba, Brazil.

5 Doctor. Doctor. Professor of the Graduate Program in Social Medicine Federal University of Rio de Janeiro, Rio de Janeiro, Brazil.

6 Physiotherapist, Doctor in Nursing from the Federal University of Paraíba. João Pessoa, Paraíba, Brazil.

7 Physiotherapist, Doctor. Professor of the Graduate Program in Nursing, Federal University of Paraíba. João Pessoa, Paraíba, Brazil.

\section{Contact information:}

Ana Margareth Marques Fonseca Sarmento.

झ ana-margareth@hotmail.com 
Conclusion: In this study, the elderly evaluated their quality of life as good and were satisfied with their health.
Keywords

Quality of Life; Elderly;

Knowledge.

\section{Introduction}

The increasing number of the elderly population occurred in Brazil took radical and accelerated way, considered an unprecedented event that has been following a worldwide phenomenon, which affects the society and reflects the actions turned to the specific needs of the elderly.

This reality reflects the socio-cultural changes that have occurred in the country with a life expectancy exceeding 73 years old, thus enabling the elderly new ways of experiencing this phase of life, with more quality and new possibilities.

The demographic transition represents a major impact on society, but it is in health that has greatest influence, both for its impact on the various assistance levels as the demand for new features and structures

The elderly suffer with the biological phenomenon of aging in a singular and unique way, characterized by loss of organic capacity; however, this natural process is provided for in human evolution, so that the elderly individual is not considered unable to have aged, and the most common diseases in this stage of diagnosable and treatable life [1].

Thinking thus prolonging life is goal of any society, but this achievement should add quality to years, bringing a new meaning to life, turning to comprehensive health care. The health of the elderly is a priority in the health ministry's actions, enacted from the National Health Policy for the Elderly (PNSPI), emphasized multidimensional way [2].

Currently the government's efforts to support actions turned to the elder are observed through the agency of the Ministry of Health to prioritize the health agenda of the country PNSPI, which under the SUS, ensures comprehensive health care of the elderly population, emphasizing the healthy aging and active addressed in a multidimensional way. The World Health Organization presents the main challenges facing the world related to the aging population, recommending that health policy takes into account the determinants of health during the course of life (social, economic, behavioral, personal, cultural, as well as physical environment and access to services), with emphasis on gender and social inequalities [3].

The image of contemporary elderly has surpassed the traditional old age context, the most dynamic and participatory characteristics in certain social situations. While some people present decline in health and cognitive skills early, others live healthy until they reach very advanced ages. The increasing number of elderly in the country is one of the greatest public health challenges, particularly the lack of economic socio-political structure that sustains the elderly [4].

To assess the health conditions of the elderly, it is directly related to quality of life, influenced by gender, age, education and living conditions.

Concern about the quality of life of the elderly is inherent in living conditions that will face as a promise to their health conditions occur; since due to imminent longevity, there is a prevalence of changes in health status that worries researchers and policymakers associated with being elderly [5].

Thus, quality of life is an expression that is of great complexity, given the subjectivity that is for each person or social group, presupposes the ability to make a synthesis of all the elements that a given society considers standard of comfort and well-being, reflects knowledge, experience and individual and collective values [6]. 
Thus, quality of life is a concept considered interdisciplinary, which is the involvement of several knowledge areas for its improvement, and may be associated with absence of illnesses, particularly symptoms or disorders; however, this concept and reductive since the same is best understood as the maintenance of health in all aspects of human life: physical, social, psychological and spiritual [7].

Interest in studies about quality of life, emerged from World War II when it was used the good life term to refer to the conquest of material goods. The concept was expanded and started to measure how much a society is developed economically. The creation of economic indicators allowed comparing the quality of life of different countries and cultures. Later, the term designated in addition to economic growth, social development [8].

The interest related to the quality of life comes from a movement within the human and biological sciences, in order to improve the health, reducing mortality and increasing life expectancy. In the late twentieth century (90's) quality of life began to be discussed by society and the media in general, leading to advances in scientific research, seeking to understand the subject and its relation to sociocultural and biological questions. The World Health Organization was organized around experts from different regions to form groups of studies on quality of life and develop assessment tools within a cross-cultural perspective [9].

According to the World Health Organization, the concept of quality of life (THE WHOQOL GROUP) is subjective and multidimensional, covering positive and negative elements, being understood as the "perception of the individual and his position in life, taking into account the cultural context and value systems assigned to it in relation to their goals, expectations, standards and concerns [5].

Initially it was elaborated that the quality assessment tool life WHOQOL-100 consists of 100 items to be answered in Likert scale, distributed in six areas: psychological, physical, level of inde- pendence, social relationships, environment and spirituality. Later an abbreviated version of this instrument according to the need to develop its application is designed, the WHOQOL-BREF is composed of four domains: physical, psychological, social relations and the environment. After a while, assessing the quality of life in the adult population, created a complementary module to be added to existing instruments, the WHOQOL-OLD, specific to assess older adults contemplating its specificities, is an add-on module to be applied along with WHOQOL-BREF, and currently already establishes a reliable instrument for use with scientific purposes validated in Brazil. The quality of life measures are important regarding the health evaluation, both within the individual and social perspectives, because of multiple rating scales present in the instrument that attempts to answer the apparent contradiction between old age and wellbeing/old age and disease, contributed to the understanding of aging and the limits and space of human development [10].

Quality of life can be called different approaches; however, its foundation covers aspects that contribute to the well being of man, a good level of health and human development. It consists of non-material values such as love, freedom, solidarity and social inclusion, personal satisfaction and happiness; also should be considered in the same way some components capable of measuring and comparing such as meeting the most basic needs of human life, such as food, access to clean water, housing, work, education, health and leisure, that is, objects materials that give the idea of well-being and comfort, as well as individual and collective satisfaction [8].

The level of satisfaction with family, affection, and social environment reflects directly on the quality of life. The individual well-being and satisfaction are directly related to the way people face life experiences. In this sense, quality of life comes to differentiate health regarding the dimensions of mental 
health, physical function and psychosocial wellbeing covering a semantic field of many meanings, considering the collective conceptions of comfort and tolerance, determined by society. However the multidimensionality of a person is reflected from the conditions of their domains: physical, psychological, level of independence, social relationships, environment and spiritual aspects, not always provides the right balance and needs to be realized in accordance with the real possibilities for each subject in the health/disease [11].

Talking about quality of life in the elderly holds, beyond health fields, such as: the environment, economic resources, relationships, work and leisure. It should take into account self-esteem, functional capacity, socioeconomic status, emotional state, social interaction, intellectual activity, self-care, family support, health, cultural, ethical and religious values, lifestyle, satisfaction including from employment, daily activities and the environment in which they live. For the elderly's quality of life is based on the well-being that comes from satisfaction with their accomplishments, that is, quality of life is largely determined by the autonomy and independence from existing chronic diseases [12].

When we discuss quality of life, an important point to be mentioned concerns the welfare of people with spiritual beliefs, to be more positive in the face of disease, hopeful about the health treatment, showing that religion and spirituality can help in social support and psychological adjustment. Other important aspects involve the faith and resilience to face the situations of adversity to deal with stress and thus improve the quality of life [13].

General or holistic approaches to quality of life are based on the principle of multidimensionality of the concept, it presents a complex organization and dynamics of its components, differs from person to person according to their environment/ context and even between two people engaged in a similar context. Features such as values, in- telligence and interests are important to be considered; also address quality of life as a social representation created from subjective and objective parameters related basic needs and those created by the degree of economic and social development of a given society. Consider aspects of being able to take advantage of the possibilities of life, to choose, to decide and take control of life [9].

When investigating the quality of life in a multidimensional way it identifies the main aspects to be considered in relation to the singularities involving the health of the elderly, influencing the healthdisease process [9].

Thus, evaluating the quality of life for seniors and their health conditions, allows us to propose interventions through public policies aimed at promoting the welfare and improvement of life for seniors.

Thus, the quality of life of older people is the object of research, to contribute to the understanding of health and possible to recognize the factors that influence the quality of life. Therefore, this study aimed to evaluate the quality of life of elderly patients in health strategy teams of family in the city of Joao Pessoa/PB, in which we achieved success as can be seen from the results described in this study.

\section{Methods}

It is a study of secondary database of a quantitative approach, seeking to assess the quality of life of seniors.

The study was conducted in the city of João Pessoa (JP) - Paraíba/Brazil, the Health Strategy Units of the Family Grotão I and II and the Community Maria Nazare, the scope of Sanitary District II.

It was composed of 250 elderly men and women living in the urban area of the municipality of João Pessoa/PB, attended at Family Health Strategy Units chosen at random.

Inclusion criteria were: being 60 years old or over according to criteria of the World Health Or- 
ganization, living in census tracts in the city for more than six months, presenting cognitive conditions to answer to the instrument and take part in the study.

The research followed the ethical criteria established in Resolution 466/2012 - Ministry of Health/National Health Board/National Research Ethics Commission (BRAZIL, 2012), governing research with human beings, having been the research participants accordingly informed as the objectives of the work, being free to join, and once accepted, they signed the Informed Consent and Informed (IC).

Data collection was carried out between the months of May to July 2010 being used as an instrument a questionnaire with information about socio-demographic data of the study subjects, which allowed the characterization of the profile of the elderly, as well as the WHOQOL-BREF and WHOQOL-OLD, aimed at measuring the quality of life of the elderly.

The WHOQOL-BREF is an instrument with psychometric properties satisfactory in the investigation of QOL in Brazilian elderly, has 26 items, two related to global QOL and general health, and the 24 others being categorized into four domains (Physical, Environmental, Social Relations and Psychological). The domains comprise questions whose answers the scores ranging between 1 and 5 [10].

The WHOQOL-OLD consists of 24 questions separated into six facets, forming an additional domain incorporating issues related to aging. The facets are: Sensory Skills (impact of the loss of their sensory abilities in the individual's QOL), autonomy (independence of the elderly), past-present and future activities (satisfaction with achievements in life and goals to be achieved), Social participation (participation in activities of daily living, especiaIly in the community), Death and dying (concerns about death and dying) and Intimacy (ability to have intimate and personal relationships) [9]. From this, the final scores of each domain and facet were calculated by syntax, based on the criteria proposed by the WHOQOL Group, which ranks the domains of $\mathrm{QOL}$, with percentage scores ranging from 0 to 100. The closer to 100, the better the individual's QOL [10].

Data were tabulated in Microsoft Excel 2007 and then processed in SPSS program (Statistical Package for Social Science) version 13.0. When we make a statistical analysis by building simple frequency tables and descriptive measures for socio-demographic data and made the codification of the relevant variables, proceeding data consistency for the WHOQOL-Bref and WHOQOL-Old.

The psychometric properties of the WHOQOLBREF instrument, and also the WHOQOL-OLD, were verified through the evaluation of reliability and validity. We calculated the Cronbach Alfa Coefficient $(\alpha)$ to check the internal consistency of the instrument to sample.

For exploratory analysis we calculated the distribution measures (average, median, standard deviation and absolute frequency), considering the variables of interest for the characterization of study participants. To compare the fields and facets of QOL with sociodemographic variables there were used the following statistical tests: Student t test, Mann-Whitney test, ANOVA test, Factor KruskalWallis test. The significance level adopted for this study was $5 \%(p<0.05)$, with a statistical confidence level of $95 \%$.

\section{Results}

The sociodemographic characteristics of the sample studied, there was prevalence of female elderly (70.4\%); older "young", aged between $60-79$ years old (85,2\%), married (44.8\%), with low education level, between $1-4$ years of education (30.4\%), and with family income 1-3 minimum wages (70.8\%) (Table 1).

In the global assessment of quality of life it was possible through the WHOQOL-Bref to evaluate the perception of the elderly about the 


\section{INTERNATIONAL ARCHIVES OF MEDICINE \\ Section: Global Health \& Health Policy

Vol. 8 No. 260

doi: $10.3823 / 1859$

Table 1. Demographic profile of the elderly in the Family Health Strategy, João Pessoa-PB. 2015.

\begin{tabular}{|c|c|c|}
\hline Variables & $\mathbf{n}$ & $\%$ \\
\hline \multicolumn{3}{|l|}{ Gender } \\
\hline Female & 176 & 70.4 \\
\hline Male & 74 & 29.6 \\
\hline \multicolumn{3}{|l|}{ Age (years) } \\
\hline $60-64$ & 68 & 27.2 \\
\hline $65-69$ & 63 & 25.2 \\
\hline $70-74$ & 65 & 26.0 \\
\hline $75-79$ & 16 & 6.4 \\
\hline 80 or over & 38 & 15.2 \\
\hline \multicolumn{3}{|l|}{ Age classification } \\
\hline Younger elderly & 213 & 85.2 \\
\hline Older elderly & 37 & 14.8 \\
\hline \multicolumn{3}{|l|}{ Marital status } \\
\hline Single & 35 & 14.0 \\
\hline Married & 112 & 44.8 \\
\hline Divorced & 20 & 8.0 \\
\hline Widower & 83 & 33.2 \\
\hline \multicolumn{3}{|l|}{ Schooling (years) } \\
\hline Illiterate & 28 & 11.2 \\
\hline $1-4$ & 76 & 30.4 \\
\hline $5-8$ & 67 & 26.8 \\
\hline $9-11$ & 32 & 12.8 \\
\hline 12 or more & 47 & 18.8 \\
\hline \multicolumn{3}{|l|}{ Monthly household income } \\
\hline Up to 1 minimum wage & 7 & 2.8 \\
\hline $\begin{array}{l}\text { Between } 1 \text { and } 3 \text { minimum } \\
\text { wages }\end{array}$ & 177 & 70.8 \\
\hline $\begin{array}{l}\text { Between } 4 \text { and } 5 \text { minimum } \\
\text { wages }\end{array}$ & 31 & 12.4 \\
\hline $\begin{array}{l}\text { Between } 6 \text { and } 7 \text { minimum } \\
\text { wages }\end{array}$ & 10 & 4.0 \\
\hline $\begin{array}{l}\text { Between } 8 \text { and } 10 \text { minimum } \\
\text { wages }\end{array}$ & 10 & 4.0 \\
\hline More than 10 minimum wages & 2 & 0.8 \\
\hline Don't know/don't mean & 13 & 5.2 \\
\hline
\end{tabular}

Table 2. Perceptions of quality of life of the elderly from the WHOQOL-BREF. João Pessoa-PB. 2015.

\begin{tabular}{|l|c|c|}
\hline \multicolumn{1}{|c|}{ Perception of QOL } & $\mathbf{n}$ & \% \\
\hline Evaluation of QOL & & \\
\hline Bad & 7 & 2.8 \\
\hline More or less & 87 & 34.8 \\
\hline Good & 130 & 52.0 \\
\hline Very good & 26 & 10.4 \\
\hline Satisfaction with the health & & \\
\hline Very dissatisfied & 2 & 0.8 \\
\hline Dissatisfied & 40 & 16.0 \\
\hline Neither unsatisfied nor satisfied & 67 & 26.8 \\
\hline Satisfied & 126 & 50.4 \\
\hline Very satisfied & 15 & 6.0 \\
\hline
\end{tabular}

QOL and satisfaction with health. The answers showed that $52.0 \%$ of seniors considered their good QOL and 50.4\% were satisfied with their health (Table 2).

The quality of life depends on intrinsic factors (health and attitudes to life events); and extrinsic (social, financial and environmental) that surround individuals [14]. In this study by comparing the QOL scores for the domains of the WHOQOL-BREF, by gender; classification by age group; marital status; education; monthly family income. The results show that the highest average scores across domains were among men, younger elderly, divorcees and singles, the higher education levels and higher incomes and the Psychological domain was with the highest average among these elderly (Table 2 ).

The QOL is a subjective concept strongly influenced by culture and all these sociodemographic variables [15]. It is observed that even in a female majority sample, males presented higher averages.

Regarding age, the younger elderly (under 80 years old) had the best averages of QOL scores in the areas "Physical" and "Psychological".

Assigning highest average to these areas indicates that the aspects evaluated in the "Body" field as 


\section{INTERNATIONAL ARCHIVES OF MEDICINE \\ Section: Global Health \& Health Policy \\ ISSN: 1755-7682}

Vol. 8 No. 260

doi: $10.3823 / 1859$

the intensity of pain and how it interferes with daily activities, the need of medical treatment, the energy required for the development of daily activities in the perception of these seniors do not interfere with their day-to-day, as well as the dimensions perceived from the domain "Psychological".

Regarding the elderly "older" the highest averages were attributed to the domains "Social Relations" and "Environmental.

When comparing the QOL and the marital status of the elderly, the highest average scores were among divorced and lonely elderly, the first in the area "Physical", "Psychological" and "Environmental" and the elderly alone in "Social Relations".
In this study, it was observed that those older adults with higher education levels had higher scores in all domains.

About family income of the elderly who earn more than 10 minimum wages had average wages close to 100, which means excellent quality of life, on the other hand those who earned less than the minimum wage, had dominion which was below 50 meaning the lowest scores.

The areas which were significant statistics were: Physical, Psychological and Environmental. These domains incorporate important dimensions of elderly life are required for maintaining the functionality and the ability to exercise their daily activities.

(Table 3)

Table 3. Scores of domains of quality of life of the WHOQOL-BREF according to socio-demographic data of the elderly, João Pessoa-PB, 2015.

\begin{tabular}{|c|c|c|c|c|}
\hline \multirow{2}{*}{ Variables } & \multicolumn{4}{|c|}{ WHOQOL-BREF } \\
\hline & Physical & Psychological & Social relations & Environmental \\
\hline \multicolumn{5}{|l|}{ Gender } \\
\hline Female & 61.13(16.85) & $64.69(12.90)$ & $64.6(14.47)$ & $56.04(12.43)$ \\
\hline Male & $62.35(14.63)$ & $68.77(12.11)$ & $66.44(14.72)$ & $57.29(13.00)$ \\
\hline p-value & $0.480 * *$ & $0.030 * *$ & $0.198 * *$ & $0.475^{\star}$ \\
\hline \multicolumn{5}{|l|}{ Classification of age } \\
\hline Younger elderly & $62.43(15.75)$ & $66.54(12.49)$ & $65.37(14.72)$ & $56.47(12.79)$ \\
\hline Older elderly & $56.08(17.91)$ & 62.16(13.93) & $65.09(13.58)$ & 56.08(11.55) \\
\hline p-value & $0.030 * *$ & $0.037 * *$ & $0.690 * *$ & $0.862 *$ \\
\hline \multicolumn{5}{|l|}{ Marital status } \\
\hline Single & $60.00(13.52)$ & 63.92(13.13) & 67.61(15.62) & $56.51(14.36)$ \\
\hline Married & 64.07(13.95) & $68.05(11.20)$ & $66.22(12.89)$ & $57.10(11.34)$ \\
\hline Divorced & $68.21(16.78)$ & $70.20(13.12)$ & $65.00(18.84)$ & $58.28(15.74)$ \\
\hline Widower & 57.01(18.76) & $62.78(13,12)$ & $63.25(15,01)$ & $54.98(12.68)$ \\
\hline$p$-value & $0.013 * * * *$ & $0.011 * * * *$ & $0.313 * * * *$ & $0.607 * * *$ \\
\hline \multicolumn{5}{|l|}{ Schooling (years) } \\
\hline Illiterate & $58.22(12,98)$ & $58.03(10.81)$ & $61.90(12.09)$ & 49.88(10.15) \\
\hline $1-4$ & $58.2(17.03)$ & $65.16(12.40)$ & $64.80(15.90)$ & $55.12(11.93)$ \\
\hline $5-8$ & $61.03(17.11)$ & $66.62(13.90)$ & $65.54(14.92)$ & $55.87(12.39)$ \\
\hline 9-11 & $67.63(11.21)$ & $70.31(10.46)$ & 70.05(11.56) & $60.03(11.37)$ \\
\hline 12 or more & $65.34(16.70)$ & $67.73(12.54)$ & $64.71(14.56)$ & $60.70(14.19)$ \\
\hline p-value & $0.008 * * * *$ & $0.001 * * * *$ & $0.216 * * \star *$ & $0.002 * * *$ \\
\hline
\end{tabular}




\begin{tabular}{|c|c|c|c|c|}
\hline \multirow{2}{*}{ Variables } & \multicolumn{4}{|c|}{ WHOQOL-BREF } \\
\hline & Physical & Psychological & Social relations & Environmental \\
\hline \multicolumn{5}{|l|}{ Monthly household income } \\
\hline Up to 1 minimum wage & $59.18(21.90)$ & $64.88(15.93)$ & $57.14(20.08)$ & $46.87(8.65)$ \\
\hline $\begin{array}{l}\text { Between } 1 \text { and } 3 \\
\text { minimum wages }\end{array}$ & $60.19(15.52)$ & $64.07(12.34)$ & $64.54(14.42)$ & $54.48(11.10)$ \\
\hline $\begin{array}{l}\text { Between } 4 \text { and } 5 \\
\text { minimum wages }\end{array}$ & $61.05(16.91)$ & $70.16(12.86)$ & $65.32(14.92)$ & $60.58(14.38)$ \\
\hline $\begin{array}{l}\text { Between } 6 \text { to } 7 \text { minimum } \\
\text { wages }\end{array}$ & $67.85(12.25)$ & $67.91(11.79)$ & $73.33(10.24)$ & $67.18(14.45)$ \\
\hline $\begin{array}{l}\text { Between } 8 \text { to } 10 \\
\text { minimum wages }\end{array}$ & $74.28(18.95)$ & $77.08(13.35)$ & $75.00(11.78)$ & $70.31(6.79)$ \\
\hline $\begin{array}{l}\text { More than } 10 \text { minimum } \\
\text { wages }\end{array}$ & $85.71(5.05)$ & $81.25(8.83)$ & $83.33(23.57)$ & $76.56(11.04)$ \\
\hline Don't know/don't mean & $62.91(16.84)$ & $68.58(10.97)$ & $64.10(10.42)$ & $55.76(15.77)$ \\
\hline$p$-value & $0.014 * * * *$ & $0.004 * * * *$ & $0.063 * * * *$ & $0.000 * * *$ \\
\hline
\end{tabular}

When comparing facets of $\mathrm{QOL}$ of the elderly with sociodemographic variables, it was observed that the age group is significantly related to the Sensory Abilities facet. The changes of the sense organs that occurs in the aging process is configured as an important factor in determining the elderly QOL as it can hinder the interaction of the elderly in social and family environment. Thus evaluation is essential in the detection of its decline and the formulation of strategies to help people to have an active aging [16].

When analyzing the marital status, it was found that this variable was significantly associated with three facets of quality of life: Sensory Skills, Social Participation and Intimacy. Divorced elderly had better averages for sensory abilities and social participation, this result is contrary to that found in studies that show that perceptions of quality of life in these facets are better in married elderly [17, 18].

In addition, the school also has a statistically significant relationship with some aspects of quality of life in the elderly (Sensory operation, Past-PresentFuture Activities and Intimacy). These facets mean important aspects in the life of the elderly, such as sensory abilities and the intimate and personal relationships of the elderly, as well as describe the satisfaction on the achievements in life and the things you desire [19].

Family income was the variable that relates statistically significantly as more facets of QOL (Sensory Skills, Social Participation, Death and Dying, Intimacy). (Table 4)

\section{Discussion}

These findings corroborate research with elderly domiciled in different Brazilian regions [20,21]. A similar result was observed in cross-sectional study developed with elderly living in the community, in the urban area of the municipality of Uberaba-MG, which dominated the self-assessment of quality of life as good (67.3\%) and satisfactory health (64.4\%) [22].

The elderly quality of life can be perceived as the way the elderly experiencing old age and can be influenced by several factors, such as physical, psychological and spiritual as well as social, economic and political. Thus, successful aging can be 


\section{INTERNATIONAL ARCHIVES OF MEDICINE \\ Section: Global Health \& Health Policy \\ ISSN: 1755-7682}

Table 4. Comparison between the scores of the facets of the quality of life of the WHOQOL-OLD with socio-demographic variables of elderly, João Pessoa-PB, 2015.

\begin{tabular}{|c|c|c|c|c|c|c|}
\hline \multirow{2}{*}{ Variables } & \multicolumn{6}{|c|}{ WHOQOL OLD } \\
\hline & FS & AUT & PPF & PSO & MEM & INT \\
\hline \multicolumn{7}{|l|}{ Gender } \\
\hline Female & 69.24(19.47) & $60.61(14.87)$ & $60.04(14.34)$ & $61.39(14.93)$ & $56.28(28.28)$ & $60.22(20.45)$ \\
\hline Male & $72.21(18.71)$ & $60.89(14.07)$ & $63.26(16.90)$ & $63.17(14.97)$ & $64.44(25.44)$ & $63.26(20.63)$ \\
\hline p-value & $0.269 * *$ & $0.511 * *$ & $0.076 * *$ & $0.492 * *$ & $0.055^{\star *}$ & $0.240 *$ \\
\hline \multicolumn{7}{|l|}{ Age } \\
\hline $60-64$ & $74.26(17.49)$ & 61.48(1643) & $62.22(15.92)$ & $62.86(15.34)$ & $53.21(29.46)$ & 65.16(19.59) \\
\hline $65-69$ & $73.80(20.10)$ & $61.30(11.71)$ & $62.69(14.63)$ & $63.78(13.70)$ & $59.02(27.74)$ & $63.49(19.96)$ \\
\hline $70-74$ & $68.26(18.88)$ & $62.59(15.64)$ & $59.42(15.82)$ & $61.25(16.50)$ & $63.17(25.96)$ & $56.63(23.27)$ \\
\hline $75-79$ & $66.01(20.66)$ & $59.37(14.96)$ & $60.15(15.79)$ & $61.71(13.28)$ & $63.28(25.40)$ & $58.98(13.49)$ \\
\hline 80 or over & $61.51(18.17)$ & $55.59(12.97)$ & $59.04(13.52)$ & $58.38(14.03)$ & $58.38(27.65)$ & $58.55(19.35)$ \\
\hline p-value & $0.006 * * * *$ & $0.172 * * * *$ & $0.685^{* * * *}$ & 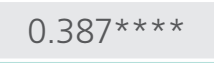 & $0.340 * \star \star *$ & $0.241 * * *$ \\
\hline \multicolumn{7}{|l|}{ Marital status } \\
\hline Single & $66,78(21.58)$ & $60.00(15.47)$ & $60.00(11.76)$ & $60.53(15.29)$ & $56.60(27.61)$ & $55.35(22.28)$ \\
\hline Married & $72.43(17.60)$ & $61.04(13.21)$ & $62.72(14.23)$ & $64.56(12.87)$ & $60.60(26.84)$ & $65.90(17.91)$ \\
\hline Divorced & $80.31(16.98)$ & $65.62(16.53)$ & $65.62(15.77)$ & $66.56(14.66)$ & $53.43(33.89)$ & $62.81(17.49)$ \\
\hline Widower & 65.96(19.79) & $59.33(15.53)$ & $57.98(17.08)$ & $57.83(16.50)$ & $58.28(27.47)$ & $56.70(22.38)$ \\
\hline$p$-value & $0.008 * * * *$ & $0.140 * * * *$ & $0.140 * \star \star *$ & $0.008 * * * *$ & $0.850 * * \star *$ & $0.013 * * *$ \\
\hline
\end{tabular}

Schooling (years)

\begin{tabular}{|l|c|c|c|c|c|c|}
\hline Illiterate & $64.50(14.63)$ & $56.9(13.81)$ & $53.79(13.53)$ & $54.91(11.70)$ & $52.23(26.69)$ & $58.03(26.56)$ \\
\hline $1-4$ & $65.21(20.08)$ & $61.26(12.41)$ & $58.79(14.79)$ & $59.86(15.72)$ & $57.73(26.47)$ & $57.64(21.00)$ \\
\hline $5-8$ & $68.93(20.06)$ & $60.35(16.62)$ & $61.38(16.06)$ & $63.43(15.35)$ & $64.08(26.79)$ & $62.03(19.25)$ \\
\hline $9-11$ & $75.97(15.80)$ & $61.13(13.06)$ & $66.99(13.95)$ & $69.33(13.41)$ & $63.47(27.50)$ & $61.91(19.33)$ \\
\hline 12 or more & $79.12(17.78)$ & $62.36(16.35)$ & $64.22(14.37)$ & $62.23(13.66)$ & $53.19(30.50)$ & $66.75(17.34)$ \\
\hline p-value & $0.000^{* * * *}$ & $0.252^{* * * *}$ & $0.003^{* * * *}$ & $0.000^{* * * *}$ & $0.153^{* * * *}$ & $0.198^{* * *}$ \\
\hline
\end{tabular}

Monthly household income (minimum wages)

\begin{tabular}{|l|c|c|c|c|c|c|}
\hline Up to 1 & $62 .(13.50)$ & $66.07(10.11)$ & $61.60(11.80)$ & $58.92(14.36)$ & $53.57(21.60)$ & $57.14(28.28)$ \\
\hline Between 1 and 3 & $68.60(18.96)$ & $59.46(14.33)$ & $59.21(14.21)$ & $60.66(14.63)$ & $57.90(27.02)$ & $57.94(20.09)$ \\
\hline Between 4 and 5 & $75.00(19.76)$ & $62.90(17.74)$ & $64.31(19.24)$ & $63.91(18.23)$ & $57.25(29.05)$ & $68.34(21.03)$ \\
\hline Between 6 and 7 & $80.00(17.87)$ & $61.87(8.56)$ & $65.00(15.92)$ & $66.87(14.14)$ & $80.62(29.82)$ & $71.87(16.20)$ \\
\hline Between 8 and 10 & $83.12(15.87)$ & $70.00(11.71)$ & $70.00(13.11)$ & $71.87(10.31)$ & $66.87(32.01)$ & $70.00(11.33)$ \\
\hline $\begin{array}{l}\text { More than 10 } \\
\text { Don't know/don't }\end{array}$ & 96.87(4.41) & $71.87(4.41)$ & $75.00(0.00)$ & $78.87(4.41)$ & $87.50(8.83)$ & $65.62(22.09)$ \\
\hline $\begin{array}{l}\text { mean }\end{array}$ & & $59.61(16.46)$ & $64.90(17.59)$ & $62.01(11.82)$ & $48.07(25.56)$ & $73.55(18.60)$ \\
\hline
\end{tabular}

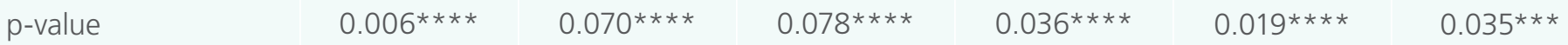

${ }^{(*)}$ Test T Student $\left(^{* *}\right)$ Test Mann-Whitney $\left(^{* * *}\right)$ Test Anova 1 Factor $\left.{ }^{* * * *}\right)$ Test of Kruskal-Wallis. FS= sensory skills, AUT= autonomy, APPF= past-present-future activities, PSO= social participation, MEM= death and dyeing, INT= intimacy 
understood as the combination of low probability of illness and disability, maintenance of the physical and cognitive functions, engagement in life, including productive activities, spirituality, interpersonal relationships and good living conditions [23, 24].

Corroborating national studies $[25,26]$ indicating that even women live longer than men, they have worse quality of life indicators for experiencing greater biological weakness before death, which needs to be considered in the evaluation of the elderly by health professionals.

The aging process is multifactorial, individual and progressive that dependent on genetic programming and the changes that occur in cell-molecular level. However, these age-related changes occur in discrete ways without compromising the relationships and individual autonomy, so aging is not considered a disease [27].

Self-esteem, positive thinking, concentration, appearance, religion are related to the phychologic domain showing that these seniors are still able to manage their life, maintain self-esteem and emotional balance, giving them the name of healthy elderly [10]

The higher averages attributed to the domains "Social Relations" and "Environmental" that these privileged interpersonal relationships, the support they receive from friends, safe environment, adequate housing and access to information that help the challenges of society. This is because these seniors groups give importance to values such as family ties, responsibility for maintenance to the family and the role of faith to the achievement of healthy aging [28].

When comparing the QOL and the marital status of the elderly, the highest average scores were among divorced and lonely elderly, the first in the area "Physical", "Psychological" and "Environmental" and the elderly alone in "Social Relations". This result demonstrates that even alone or experiencing a marital separation did not interfere with their quality of life as shown by the high mean scores. This may be related to the fact that the elderly live in their homes, with families or alone is more likely to develop various activities at home or elsewhere, this generating satisfaction, while maintainingselfesteem and even carrying several morbidities they do not interfere with their autonomy and independence [29].

The national literature pointing to education as an important factor that interferes with the individual's $\mathrm{QOL}$, as it allows access to information, understanding his rights and duties as citizens and facilitates their access to health education programs [30, 31].

Insufficient family income is an indicator of precariousness in the elderly living conditions directly interfering with their QOL as it implies diverse needs of care of elderly difficulties in life is, in the physical, social and psychological context [32].

The results indicates that not only physical aspects such as pain, medications and other need to be considered in the health assessment of the elderly, but issues such as self-esteem, spirituality, concentration, learning, memory, secure environment, financial resources to meet their needs, leisure, freedom and power to decide their life and others.

In the face of such evidence, it can be inferred the education has an important influence on the aspects of old life, suggesting that educational policies are formulated aimed at the elderly, which correspond to their needs.

In relation to the result referring to the family income he corroborates in part to study conducted with 1,806 elderly women who participated in the movement Elderly program [17]. These facets assessed in addition to changes in the organs of the sensory apparatus, the insertion of the elderly in social activities and the relationship with friends and family, as well as concern about death issues, and points out that the best scores in these facets of quality of life are directly associated with a favorable economic condition of the elderly. 


\section{Conclusion}

In this study, subjects evaluated their quality of life as good and were satisfied with their health. Sociodemographic factors (gender, age, education, marital status and household income) are related to quality of life for seniors. It is noteworthy that the Psychological domain and facet sensory abilities showed a significant relationship with the sociodemographic characteristics of the elderly, indicating that need to be considered in assessing complete health of the elderly.

The results of this study can contribute to the expansion of actions to promote health and quality of life of seniors. Interventions should be formulated especially for the elderly in vulnerable situations whether physical, social or environmental.

\section{References}

1. Martin GB. et al. Assistência hospitalar à população idosa em cidade do sul do Brasil. Epidemiol. Serv. Saúde, Brasília, 2006; 15(1); 59-65. http://scielo.iec.pa.gov.br/pdf/ess/ v15n1/v15n1a05.pdf

2. Veras R. Envelhecimento Populacional Contemporâneo: demandas, desafios e inovações. Revista Saúde Pública, São Paulo. 2009; 43(3): 548-54. http://www.scielosp.org/pdf/rsp/ v43n3/224.pdf

3. Brasil. Ministério da Saúde. Portaria $n^{\circ} 2.528$, de 19 de outubro de 2006. Aprova a Política Nacional de Saúde da Pessoa Idosa. Diário Oficial da União, 20 out. 2006. http://bvsms. saude.gov.br/bvs/publicacoes/atencao saude pessoa idosa envelhecimento $v 12 . p d f$

4. Silva LM. et al. Representações sociais sobre qualidade de vida para idosos. Rev. Gaúcha Enferm. Porto Alegre (RS). 2012; 33(1): 109-15, Disponível em: www.scielo.br/scielo.php?pid=S198314472012000100015\&script>. Acesso em: 25 out. 2014.

5. Whoqol Group. The World Health Organization quality of life assessment: position paper from the world health organization. Soc Sci Med.1995; 4(1): 1403-1409.doi.org/10.1590/S141381232000000100004

6. Gordia AP. et al. Qualidade de vida: contexto histórico, definição, avaliação e fatores associados. Rev. Brasil. Qualid. de Vida Universidade Tecnológica Federal do Paraná -Ponta Grossa/PR. 2012; 03(01): 40-52. doi: 10.3895/S2175-08582012000100005
7. Pimenta FAP. et al. Avaliação da qualidade de vida de aposentados com a utilização do questionário SF-36. Rev. Assoc. Med. Bras. Belo Horizonte. 2008; 54(1): 55-60. doi.org/10.1590/S180998232013000300006

8. Martins C R. et al. Avaliação da qualidade de vida subjetiva dos idosos: uma comparação entre os residentes em cidades rurais e urbanas. Estud. Interdiscip. Envelhec. Porto Alegre. 2007; 11(02): 135-54. http://webcache.googleusercontent. com/search?q=cache: ZugWy6D1ui0J: www.seer.ufrgs.br/ RevEnvelhecer/article/download/4817/2715+\&cd=1\&hl=ptBR\&ct=clnk\&gl=br

9. Santos SR. et al. Qualidade de vida do idoso na comunidade: aplicação da escala de Flanagan. Rev Latino-Am Enfermagem. 2002; 10(6): 757-64. doi: http://dx.doi.org/10.1590/S010411692002000600002 .

10. Fleck MPA. et al. Aplicação da versão em português do instrumento abreviado de avaliação da qualidade de vida "WHOQOL-bref". Revista de Saúde Pública. 2000; 34(2): 17883. doi.org/10.1590/S0034-89102000000200012

11. Vecchia RD. et al. Qualidade de vida na terceira idade: um conceito subjetivo. Rev Bras Epidemiol. São Paulo. 2005; 8(3): 246-52. doi.org/10.1590/\$1415-790X2005000300006.

12. Oliveira AC. et al. Qualidade de vida em idosos que praticam atividade física - Uma revisão sistemática. Revista Brasileira de Geriatria e Gerontologia. Rio de Janeiro. 2010; 13(2): 301-12. doi.org/10.1590/S1809-98232010000200014.

13. Cardona-Arias JA. Representaciones sociales de calidad de vida relacionada con la salud en personas con VIH/SIDA, Medellín, Colombia. Rev. Salud Pública. 2010; 12(5): 765-76. http://www. scielosp.org/pdf/rsap/v12n5/v12n5a07.pdf

14. Ribeiro AP. et al. A influência das quedas na qualidade de vida de idosos. Ciência \& Saúde Coletiva. Rio de Janeiro. 2008; 13(4): 1265-273. doi.org/10.1590/S1413-81232008000400023.

15. Molzahn A. et al. The importance of facets of quality of life to older adults: an international investigation. Qual. Life Res., Dordrecht. 2010; 19( 2): 293-98. doi: 10.1186/1477-7525-11136

16. Bogardus Junior ST, Yueh B, Shekelle PG. Screening and management of adult hearing loss in primary care. JAMA, Chicago2003; 289(15): 1986-990. http://www.ncbi.nlm.nih. gov/books/NBK53868/

17. Vagetti GC. et al. Condições de saúde e variáveis sociodemográficas associadas à qualidade de vida em idosos de um programa de atividade física de Curitiba, Paraná, sul do Brasil. Cad. Saúde Pública. Rio de Janeiro. 2013; 29(5): 955-69. doi.org/10.1590/S0102-311X2013000500013 
18. Erkal S, Sahin H, Surgit EB. Examination of the relationship between the quality of life and demographic and accidentrelated characteristics of elderly people living in a nursing home. Turk J Geriat. 2011; 14(1): 45-53. doi.org/10.1590/S0102$311 \times 2013000500013$

19. Chachamovicth E. et al. (Eds.) A Avaliação de qualidade de vida: Guia para profissionais de saúde. Porto Alegre. Artemed, 2008. http://www.scielo.br/scielo. php?script $=$ sci nlinks\&ref $=000120 \& p i d=s 0104$ $0707201100050002600011 \& \operatorname{lng}=p t$

20. Tavares DMS, Araújo MO, Dias FA. Qualidade de vida dos idosos: comparação entre os distritos Sanitários de Uberaba - MG. Cienc. Cuid. Saúde. Maringá, 2011; 10(1): 7481. http://www.scielo.br/pdf/tce/v21n1/a13v21n1.pdf.

21. Borim FSA. et al. Dimensões da autoavaliação de saúde em idosos. Revista de Saúde Pública. 2014; 48(5): 714-22. DOI: 10.1590/S0034-8910.2014048005243

22. Tavares DMS. et al. Qualidade de Vida e Capacidade Funcional de Idosos Residentes na Zona Rural. Rev Rene. Fortaleza. 2012. 12(9): 895-903. http://www.revistarene.ufc.br/vol12n4 esp pdf/a02v12esp n4.pdf

23. Neri AL. Qualidade de vida na velhice: enfoque multidisciplinar. Campinas: Alínea; 2007.

24. Moraes JFD, Souza VBA. Fatores associados ao envelhecimento bem-sucedido de idosos socialmente ativos da região metropolitana de Porto Alegre. Rev. Bras. Psiquiatr. 2005; 27(4): 302-208. http://www.scielo.br/scielo.php?pid=1516$444620050003 \&$ script $=$ sci issuetoc

25. Faller J W. et al. Qualidade de Vida de Idosos cadastrados na Estratégia Saúde da Família de Foz do Iguaçu-PR. Esc. Anna Nery. Rio de Janeiro. 2010; 14(4): 803-10. http://www. revistaenfermagem.eean.edu.br/default. asp?ed $=24$

26. Pereira RJ. et al. Contribuição dos domínios físico, social, psicológico e ambiental para a qualidade de vida global de idosos. Rev. psiquiatr. RS jan/abr 2006; 28(1): 27-38. http:// www.scielo.br/pdf/rprs/v28n1/v28n1a05

27. Moraes EN. et al. Características biológicas e psicológicas do envelhecimento. Rev Med Minas Gerais; 2010; 20(1): 67-73. http://www.observatorionacionaldoidoso.fiocruz.br/biblioteca/_ artigos/197.pdf

28. Caldas $C P$, Bertero CM. Living as an oldest old in Rio de Janeiro: The lived experience told. Nurs. Sci. Q. 2007; 20(03): 376-82. doi: 10.1177/0894318407306542

29. Dias DSG, Carvalho CS, Araújo CV. Comparação da percepção subjetiva de qualidade de vida e bem estar de idosos que vivem sozinhos, com a família e institucionalizados. Rev. Bras. Geriatr. Geront. Rio de Janeiro. 2013; 16(1): 127-38. doi. org/10.1590/1809-9823.2014.13012
30. Instituto Nacional de Estudos e Pesquisas Educacionais Anísio Teixeira (INEP) Mapa do analfabetismo no Brasil. Brasília, 2003. http://www.oei.es/quipu/brasil/estadisticas/ analfabetismo2003.pdf

31. Peres MAC. Velhice e analfabetismo, uma relação paradoxal: a exclusão educacional em contextos rurais da região nordeste. Soc. Estado. Brasília, 2011; 26(3): 631-662. doi.org/10.1590/ S0102-69922011000300011

32. Caldas C P. Envelhecimento com dependência: responsabilidade e demandas da família. Cad. Saúde Pública, Rio de Janeiro, 2003; 19(3): 773-781. http://www.scielosp.org/pdf/csp/ v19n3/15880.pdf

\section{Comment on this article:}

\section{(f) [3) in $8+\mathbf{S} P$}

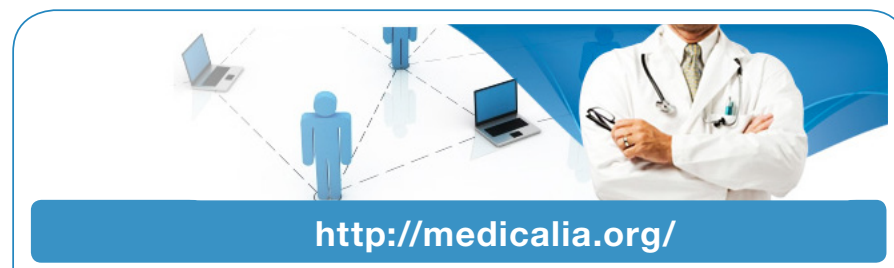

Where Doctors exchange clinical experiences, review their cases and share clinical knowledge. You can also access lots of medical publications for free. Join Now!

\section{Publish with iMedPub}

http://www.imed.pub

International Archives of Medicine is an open access journal publishing articles encompassing all aspects of medical science and clinical practice. IAM is considered a megajournal with independent sections on all areas of medicine. IAM is a really international journal with authors and board members from all around the world. The journal is widely indexed and classified Q1 in category Medicine. 